\title{
Autosomal Dominant Torsion Dystonia 1
}

National Cancer Institute

\section{Source}

National Cancer Institute. Autosomal Dominant Torsion Dystonia 1. NCI Thesaurus.

Code C118780.

An autosomal dominant inherited disorder caused by mutations in the TOR1A gene. It usually begins in childhood or adolescence and is characterized by involuntary muscle contractions in the arms, legs, trunk, and neck. 